\title{
Growth and physiological responses of sunflower plants exposed to ultraviolet-B radiation
}

\author{
Crescimento e respostas fisiológicas de plantas de girassol à radiação \\ ultravioleta-B
}

\author{
Inês Cechin $^{I^{*}}$ Terezinha de Fátima Fumis ${ }^{\mathrm{I}}$ \\ Anne Ligia Dokkedal ${ }^{\mathrm{I}}$
}

\begin{abstract}
The effects of $U V-B$ radiation were studied in sunflower plants (Helianthus annuus L. cv. Catissol-01) growning in greenhouse under natural photoperiod conditions. The plants received approximately $0.60 \mathrm{Wm}^{-2}$ (control) or $4.0 \mathrm{Wm}^{-2}$ $(+U V-B)$ of $U V-B$ radiation for $7 \mathrm{~h} \mathrm{~d}^{-1}$, centered around solar noon from 15 days after sowing. Compared to the control, plants exposed to high UV-B radiation for 12 or 21 days did not show any difference in shoot dry matter, specific leaf weight or UV-B absorbing compounds. Enhanced UV-B radiation caused a significant inhibition of photosynthesis (A) only in the first sampling and this was accompained by reduction in stomatal conductance $\left(g_{s}\right)$ and transpiration rate. The inhibition in A can not be fully explained by reduction in $g_{s}$ since intercellular $\mathrm{CO}_{2}$ concentration was not affected by UV-B radiation. In both samplings, the total chlorophyll content was not affected by enhanced UV-B radiation whereas in the first sampling, the chlorophyll $a$ and the ratio of chlorophyll $a / b$ were reduced. Enhanced UV-B radiation increased the minimal fluorescence yield, but did not alter the ratio of variable to maximal fluorescence yield of dark adapted leaves. Overall, this study suggests that the present level of solar UV-B radiation affects sunflower plants performance even though the shoot dry biomass may not be affected.
\end{abstract}

Key words: growth, Helianthus annuus, phenolics, photosynthesis.

\section{RESUMO}

Os efeitos da radiação UV-B foram estudados em plantas de girassol (Helianthus annuus L. cv. Catissol-01) cultivadas em casa de vegetação sob condições fotoperiódicas naturais. As plantas receberam aproximadamente $0,60 \mathrm{~W} \mathrm{~m}^{-2}$ (controle) ou $4,0 \mathrm{~W} \mathrm{~m}^{-2}(+U V-B)$ de radiação $U V-B$ por $7 \mathrm{~h} \mathrm{~d}^{-1}$, centralizadas ao redor do meio-dia. A irradiação com UV-B foi iniciada 15 dias após a semeadura. Plantas sob alta radiação $U V-B$ durante 12 ou 21 dias não apresentaram diferenças em matéria seca da parte aérea, peso foliar específico ou compostos que absorvem UV-B, quando comparadas com o controle. Alta radiação UV-B reduziu a taxa de fotossíntese (A) somente na primeira coleta, sendo acompanhada por uma redução na condutância estomática $\left(g_{s}\right)$ e na taxa de transpiração. A inibição da fotossíntese não pode ser somente explicada pela redução na $g_{s}$, visto que a concentração intercelular de $\mathrm{CO}_{2}$ não foi alterada pelo aumento na radiação $U V-B$. O conteúdo total de clorofila não foi afetado pelo aumento na radiação UV-B nas duas coletas. No entanto, o conteúdo de clorofila a e a razão clorofila $a / b$ foram reduzidas na primeira coleta. Sob alta radiação UV-B, houve aumento na fluorescência mínima na primeira coleta. Porém, a razão entre a fluorescência variável e a fluorescência máxima das folhas adaptadas ao escuro não foi alterada. Estes resultados sugerem que o atual nível de radiação solar UV-B afeta o desempenho das plantas de girassol, embora a massa seca da parte aérea não seja afetada.

Palavras-chave: crescimento, fenóis, fotossíntese, Helianthus annuus.

\section{INTRODUCTION}

The fact that man-made chlorofluorocarbons have the potential to cause a depletion of ozone layer, which is responsible for the attenuation of solar UV-B radiation reaching the Earth's surface, has been proposed more than 30 years (MOLINA \& ROWLAND, 1974). The depletion of the ozone layer is closely related to an increase in UV-B radiation on the Earth's surface

IDepartamento de Ciências Biológicas, Universidade Estadual Paulista Júlio de Mesquita Filho, Faculdade de Ciências de Bauru, Av. Eng. Luiz Edmundo Carrijo Coube, CP 473, 17033-360, Bauru, São Paulo, Brasil. E-mail: icechin@fc.unesp.br.* Autor para correspondência. 
(KERR \& McELROY, 1993). Solar radiation in the UV-B range (280-320nm) corresponds to a minor percentage of the total solar energy but it is potentially harmful because these short wavelengths are capable of causing deleterius damages in cells. Plants are vulnerable to increased UV-B radiation because many cellular components such as nucleic acids, proteins, lipids and quinones can absorb UV-B radiation directly (JORDAN, 1996). Thus, the effect of increased UV-B radiation on growth and physiology of many plants, including crop and forest tree species, under both greenhouse and field conditions, has become one of the most important subjects of investigation in the last decades. Studies about the effect of natural, actual day UV-B radiation on five tropical species by excluding the UV-B radiation in natural sunlight provided evidence that tropical vegetation responds to actual level of natural solar UV-B radiation (SEARLES et al., 1995; LIU et al., 2005).

Reduction in biomass accumulation due to UV-B exposure was found in several tree (SEARLES et al., 1995; LIU et al., 2005) and crop (KAKANI et al., $2003 \mathrm{~b}$ ) species. Negative impact of enhanced UV-B radiation on cotton growth included reduction in height, leaf area, total biomass and fiber quality (GAO et al., 2003). Growth reduction is mediated through leaf expansion (PINTO et al., 1999), which is a consequence of the UV-B radiation effects on the rate and duration of both cell division and elongation (HOPKINS et al., 2002). Increased UV-B radiation exposure reduced the photosynthetic rate of many species and, in general, the reduction was more pronouced under growth chamber or greenhouse conditions than under field conditions (KAKANI et al., 2003b). Reduction in photosynthetic rate can be a consequence of damage to various molecular mechanisms of the photosynthetic machinery (JANSEN et al., 1998). However, photosynthesis can also be depleted by stomatal density and opening as well as by reduction in stomatal conductance or by reduction in the chlorophyll content (DAI et al., 1995; FENG et al., 2003).

There is evidence that UV-B absorbing pigments have adaptative value in plants that grow in regions with high UV-B radiation (ROBBERECHT \& CALDWELL, 1980). It is known that UV-B radiation induces photoprotection by increasing the production of compounds that strongly absorb UV radiation in the epidermal tissues of leaves (COOPER-DRIVER \& BHATTACHARYA, 1998; PINTO et al., 1999). The defence mechanism by increased UV-B absorbing compounds partly counteracts the harmful effects of UV-B radiation. Both field and in vitro studies have shown that certain flavonoids and non-specified phenolics can protect DNA from UV-B induced damage (KOOSTRA, 1994; MAZZA et al., 2000).

Tropical plants receive much higher levels of ambient UV-B radiation than those growing in temperate regions. The gradual decrease in UV-B radiation from Equator to poles is primary due to reduced daylight hours during the winter and to the greater distance solar radiation must pass through the atmosphere in temperate and polar regions (BARBOUR et al., 1987). Therefore, it is generally thought that tropical plants have inherent resistance to UV-B radiation.

The objetive of this study was to investigate if sunflower plants are susceptible to UV-B radiation by measuring its effetcs on growth, gas exchange characteristics and UV-B absorbing compounds.

\section{MATERIALS AND METHODS}

Sunflower (Helianthus annuus L. cv. Catissol-01) seeds were sown in $8 \mathrm{dm}^{3}$ pots filled with a mixture of pinus bark, vermiculite and peat (47\%:13\%:40\%) and a $\mathrm{pH}$ of 5.6-6.2. Seedlings were thinned to one per pot after emergency and were grown in a greenhouse at the São Paulo State University (Bauru, São Paulo State, 2221'28' S, 4901'37' W) under natural photoperiod between November and December 2004. Maximum and minimum daily temperatures were close to 33 and $21^{\circ} \mathrm{C}$, respectively. Each plant was supplied with $300 \mathrm{~cm}^{3}$ of a $50 \%$ of full strength Long Ashton solution (HEWITT, 1966) per pot twice a week, and with tap water during other days.

UV-B radiation was supplied by $40 \mathrm{~W}$ fluorescent lamps (UVB-313, Q-Panel Co., Cleveland, $\mathrm{OH}, \mathrm{USA}$ ) held in mobile adjustable frames over the plants. The system was comprised of two raisable aluminium frames. Each frame had 8 lamps, fixed at a distance of $0.5 \mathrm{~m}$ from each other. Both frames were separeted by a polyester curtain to avoid lateral UV-B radiation reaching the control plants. The distance between the lamps and the top of the plants was kept constant by the adjustable frame over the plants. In the UV-B treatment the lamps were wrapped with cellulose acetate filter $(0.10 \mathrm{~mm}$ thick; Malaga Produtos Metalizados Ltda, BR) to cut off UV-C radiation shorter than $280 \mathrm{~nm}$. In the non-UV-B radiation treatment (control), the plants were kept under lamps wrapped with polyester filter $(0.125 \mathrm{~mm}$ thick; Du Pont Co, USA), which absorbs radiation shorter than $320 \mathrm{~nm}$. These filters were replaced every four and eight days, respectively, to avoid photodegradation effects caused by UV-B radiation. The average UV-B radiation near the top of the plants was approximately $4.0 \mathrm{~W} \mathrm{~m}^{-2}$ (near

Ciência Rural, v.37, n.1, jan-fev, 2007. 
ambient level) for the UV-B treatment and $0.60 \mathrm{Wm}^{-2}$ for control. A voltage meter (Marconi Equipamentos para Laboratórios Ltda, BR) connected to a UV-B sensor with preamplifier (Delta-T Devices Limited, UK) was used to measure the radiation reaching the top of the plants. Plants were irradiated with UV-B for $7 \mathrm{~h} \mathrm{~d}^{-1}$ centered around solar noon.

The UV-B radiation treatment was initiated 15 days after sowing when plants had approximately 9 visible leaves and the length of leaves 5 and 6 (numbered acropetally) was approximately $4.0 \mathrm{~cm}$. Leaf gas exchange, chlorophyll fluorescence, chlorophyll content and UV-B absorbing compounds were determined after twelve and twenty one days of treatment.

A portable infra-red gas analyser (LCpro, ADC, Hoddesdon, UK) was used for the measurements of photosynthesis $(A)$, stomatal conductance to water vapor $\left(g_{s}\right)$, transpiration $(E)$ and intercellular $\mathrm{CO}_{2}$ concentration $\left(C_{i}\right)$. Measurements were made inside the greenhouse at photosynthetic active radiation (PAR) of $1800 \mu \mathrm{mol} \mathrm{m} \mathrm{m}^{-2} \mathrm{~s}^{-1}$, which was supplied by a light unit mounted on the top of leaf chamber. Photosynthesis was measured before samplinging the plants on leaves (5 and 13) at physiological maturity. The partial pressure of $\mathrm{CO}_{2}$ and water vapor pressure of the air (entering from outside of the greenhouse) and leaving the leaf chamber, the molar air flow rate $\left(200 \mu \mathrm{mol} \mathrm{s}^{-1}\right)$, air temperature and PAR were also recorded at the same time as the photosynthetic measurements. Rates of $A, g_{s}, E$ and $C i$ were calculated using the equations described by VON CAEMMERER \& FARQUHAR (1981). Three disks of $1.68 \mathrm{~cm}^{2}$ each of the leaves that were used for the measurements of photosynthesis and chlorophyll fluorescence were collected and used for specific leaf weight (SLW) calculations.

Chlorophyll a fluorescence was measured with a portable fluorometer (PAM-2000, Walz, Effeltrich, Germany) on the same leaves used for gas exchange determinations. Measurements of the minimal $\left(F_{o}\right)$ and maximal $\left(\mathrm{F}_{\mathrm{m}}\right)$ fluorescence yields were made early in the morning after $20 \mathrm{~min}$ of dark adaptation, thus enabling determination of ratio of variable to maximal fluorescence $\left(\mathrm{F}_{\mathrm{v}} / \mathrm{F}_{\mathrm{m}}\right) . \mathrm{F}_{\mathrm{v}} / \mathrm{F}_{\mathrm{m}}$ represents a measure of the potential efficiency of Photosystem II (PSII) in darkness.

Chlorophyll content was measured on three leaf discs of $1.68 \mathrm{~cm}^{2}$ each from the same leaf used for gas exchange, chlorophyll fluorescence and SLW. Chlorophyll was extracted in $80 \%$ acetone (ARNON, 1949). UV-B absorbing compounds were determined on dried leaves ( 6 and 14 ) next to the leaves used for gas exchange, chlorophyll fluorescence and chlorophyll content. Leaves were oven dried and fine powdered. The ground material was extracted in $6.0 \mathrm{~mL}$ of $\mathrm{MeOH}: \mathrm{HCl}$ :water (79:20:1) in the dark for 48h. At the end of the extraction period, the extract was filtered and the absorbance measured at 280, 300 and 310nm with a UV/visible spectrophometer (Cintra 10, GBC, Australia). The concentration of UV-B absorbing compounds was expressed on the basis of leaf dry weight $\left(\mathrm{A}_{\mathrm{nm}} \mathrm{mg}^{-1}\right)$.

The samplings were made after 12 and 21 one days of UV-B exposure (26 and 35 days after sowing) after determinations of gas exchange and chlorophyll $a$ fluorescence. Five plants from each treatment were randomly selected for shoot dry matter determination. The shoot biomass was oven dried at $70^{\circ} \mathrm{C}$ for at least 48 hours.

All measurements were made at least on 5-7 individual plants per treatment. Treatments were compared using Student's $t$-Test for Independent Samples at the 5\% level (SPSS/PC 9.0 for Windows)

\section{RESULTS AND DISCUSSION}

UV-B radiation did not affect shoot biomass of sunflower plants grown in the greenhouse, regardless sampling time (data not shown). These results are in agreement with previous studies that indicated no UV-B effects on growth under field and growth chamber (HAKADA et al., 2002; ZHAO et al., 2003). In a recent review by KAKANI et al. (2003b), shows that in $54 \%$ of 40 studies under greenhouse, growth chamber or field conditions reported a redution of biomass by elevated UV-B radiation while $35 \%$ of the studies reported no effect. The differences in response to enhanced UV-B radiation may be related to differences in the approaches and variation in UV-B sensitivity among species. For example, fresh and dry weight, and leaf area were reduced under UV-B only at early development stages in maize (MARK et al., 1996). The lack of an UV-B effect on biomass production in the present study may be a consequence of developmental stage at which the stress was imposed as reported by GONZÁLEZ et al. (1998). Increase in leaf thickeness has often been reported in response to UV-B radiation (DAY et al., 1993; LIU et al., 2005) and this response may reduces the UV-B damage. In this study, no increase in leaf thickeness was found which probably led the UV-B radiation reach the mesophyll and affect photosynthesis.

Inhibition of gas exchange parameters was observed only in the first sampling, except for $g_{s}$ (Table 1). $A$ was lower in plants grown under elevated UV-B radiation and this inhibition was accompained by a 
Table 1 - Gas exchange and photochemical characteristics of leaves of sunflower plants grown under low (-) and supplemented (+) UV-B radiation after 12 and 21 days of UV-B exposure (first and second sample).

\begin{tabular}{|c|c|c|c|c|c|}
\hline \multirow[b]{2}{*}{ Sample } & \multirow[b]{2}{*}{ Variable } & \multicolumn{2}{|c|}{ Leaf 5} & \multicolumn{2}{|c|}{ Leaf 13} \\
\hline & & - UV-B & +UV-B & -UV-B & +UV-B \\
\hline \multirow[t]{7}{*}{$1 \mathrm{st}$} & $C_{i}$ & $174.29 \pm 13.03 \mathrm{a}^{1}$ & $152.43 \pm 17.85 \mathrm{a}$ & $\mathrm{nd}^{2}$ & nd \\
\hline & $E$ & $5.30 \pm 0.27 \mathrm{a}$ & $3.81 \pm 0.20 \mathrm{~b}$ & nd & nd \\
\hline & $g_{s}$ & $0.41 \pm 0.05 \mathrm{a}$ & $0.20 \pm 0.02 b$ & nd & nd \\
\hline & $A$ & $26.87 \pm 0.21 \mathrm{a}$ & $19.22 \pm 0.70 b$ & nd & nd \\
\hline & $\mathrm{F}_{\mathrm{o}}$ & $0.272 \pm 0.007 \mathrm{a}$ & $0.292 \pm 0.005 b$ & nd & nd \\
\hline & $\mathrm{F}_{\mathrm{v}}$ & $1.836 \pm 0.009 \mathrm{a}$ & $1.818 \pm 0.020 \mathrm{a}$ & nd & nd \\
\hline & $\mathrm{F}_{\mathrm{v}} / \mathrm{F}_{\mathrm{m}}$ & $0.868 \pm 0.001 \mathrm{a}$ & $0.861 \pm 0.003 \mathrm{a}$ & nd & nd \\
\hline \multirow[t]{7}{*}{ 2nd } & $C_{I}$ & $257.83 \pm 9.41 \mathrm{a}$ & $235.83 \pm 4.09 \mathrm{a}$ & $208.50 \pm 8.14 \mathrm{a}$ & $190.83 \pm 9.04 \mathrm{a}$ \\
\hline & $E$ & $4.15 \pm 0.12 \mathrm{a}$ & $3.68 \pm 0.28 \mathrm{a}$ & $4.69 \pm 0.10 \mathrm{a}$ & $4.25 \pm 0.19 \mathrm{a}$ \\
\hline & $g_{s}$ & $0.39 \pm 0.03 \mathrm{a}$ & $0.29 \pm 0.05 \mathrm{a}$ & $0.53 \pm 0.04 \mathrm{a}$ & $0.37 \pm 0.04 \mathrm{~b}$ \\
\hline & $A$ & $13.63 \pm 1.15 \mathrm{a}$ & $13.88 \pm 1.08 \mathrm{a}$ & $23.70 \pm 0.67 \mathrm{a}$ & $21.94 \pm 0.69 \mathrm{a}$ \\
\hline & $\mathrm{F}_{\mathrm{o}}$ & $0.280 \pm 0.003 \mathrm{a}$ & $0.282 \pm 0.005 \mathrm{a}$ & $0.271 \pm 0.007 \mathrm{a}$ & $0.263 \pm 0.003 \mathrm{a}$ \\
\hline & $\mathrm{F}_{\mathrm{v}}$ & $1.830 \pm 0.017 \mathrm{a}$ & $1.814 \pm 0.023 \mathrm{a}$ & $1.839 \pm 0.016 \mathrm{a}$ & $1.817 \pm 0.023 \mathrm{a}$ \\
\hline & $\mathrm{F}_{\mathrm{v}} / \mathrm{F}_{\mathrm{m}}$ & $0.867 \pm 0.014 \mathrm{a}$ & $0.865 \pm 0.024 \mathrm{a}$ & $0.872 \pm 0.002 \mathrm{a}$ & $0.874 \pm 0.001 \mathrm{a}$ \\
\hline
\end{tabular}

${ }^{1}$ Values are means \pm SE of 6-7 plants. Means followed by the same letter within rows and leaves are not significantly different at $\mathrm{P}<0.05$.

${ }^{2}$ Not determined.

reduction in $g_{s}$ and $E$. These results contrast with the findings by NOGUÉS et al. (1998), who showed that $\mathrm{UV}-\mathrm{B}$ radiation increased stomatal limitation of $\mathrm{CO}_{2}$ by $15 \%$ without any reduction in $A$. However, in the second sampling $g_{s}$ of leaf 13 was reduced by UV-B radiation without affecting $A$, indicating a possible biochemical adjustment within the photosynthetic apparatus (NOGUÉS et al., 1998). JANSEN \& VAN DEN NOORT (2000) presented evidence that depending on the metabolic state of the guard cell, high fluences of UVB either stimulate stomatal opening or stomatal closing. Reduction in photosynthesis of plants exposed to high levels of UV-B radiation was due to altered stomatal functioning (NOGUÉS et al., 1999) or to both stomatal funtioning and density (GITZ et al., 2005). In sunflower plants, reductions in $g_{s}$ can not fully explain inhibition of photosynthesis because $C_{i}$ was not affected by enhanced UV-B radiation.

Some indication of the mechanisms responsible for the reduction in photosynthesis can be obtained from analysis of chlorophyll fluorescense data. $F_{o}$ is the minimal fluorescence emission from chlorophyll antennae before any photochemical event takes place and it depends on the size of PSII chlorophyll antennae and on the functional integrity of PSII reaction centers (KRAUSE \& WEISS, 1991). In the UV-B stressed sunflower plants, the decrease in $A$ observed in the first sampling was accompained by an increase in $F_{o}$ of $7.4 \%$ (Table 1), suggesting a possible damage to PSII. However, it is important to note that the potential photochemical efficiency, as measured by the ratio of variable to maximal fluorescence $\left(\mathrm{F}_{\mathrm{v}} /\right.$ $\mathrm{F}_{\mathrm{m}}$ ), was not significantly reduced by UV-B despite of a reduction of $28.5 \%$ in the rate of $\mathrm{CO}_{2}$ assimilation. Consequently, our results suggest that photodamage to PSII reaction centers is not the primary factor for decreasing $A$ in the UV-B stressed plants. In both samplings, there was no effect of increased UV-B radiation on the total chlorophyll content (Table 2). In the first sampling, chlorophyll $a$ and the ratio of chlorophyll $a / b$ decreased significantly. No effect of UV-B radiation on chlorophyll $b$ suggests that the light harvesting complex was not affected while chlorophyll $a$ seems to be more sensitive to UV-B radiation. These results may partially explain the decrease in $A$. Thus, in sunflower plants other factors may be limiting $\mathrm{CO}_{2}$ assimilation. ALLEN et al. (1997) concluded that the decrease in the rate of $\mathrm{CO}_{2}$ assimilation of oilseed rape plants under enhanced UV-B radiation is a consequence of loss in Rubisco activity and content.

The absorbance of extracts at 280, 300 and $310 \mathrm{~nm}$ was used as a measure of the protection offered by the pigments. No difference was found in absorbance at these wavelengths (data not shown). These results contrast with the findings by SEARLES et al. (2001), where one of the most evident response to UV-B radiation observed was an increase in UV-B absorbing compounds. The increase in UV-B absorbing compounds in response to enhanced UV-B radiation reported by several authors has been interpreted as an

Ciência Rural, v.37, n.1, jan-fev, 2007. 
Table 2 - Chlorophyll content $\left(\mathrm{mg} \mathrm{g}^{-1}\right)$ of leaves of sunflower plants grown under low (-) and supplemented (+) UV-B radiation radiation after 12 and 21 days of UV-B exposure (first and second sample).

\begin{tabular}{|c|c|c|c|c|c|}
\hline \multirow{2}{*}{ Sample } & \multirow[b]{2}{*}{ Variable } & \multicolumn{2}{|c|}{ Leaf 5} & \multicolumn{2}{|c|}{ Leaf 13} \\
\hline & & - UV-B & + UV-B & - UV-B & $+U V-B$ \\
\hline \multirow[t]{4}{*}{$1 \mathrm{st}$} & Chl $a$ & $1.81 \pm 0.01 \mathrm{a}^{1}$ & $1.61 \pm 0.07 \mathrm{~b}$ & $\mathrm{nd}^{2}$ & nd \\
\hline & Chl $b$ & $0.58 \pm 0.01 \mathrm{a}$ & $0.56 \pm 0.02 \mathrm{a}$ & nd & nd \\
\hline & Chl $a / b$ & $3.09 \pm 0.03 \mathrm{a}$ & $2.88 \pm 0.02 b$ & nd & nd \\
\hline & Chl total & $2.39 \pm 0.02 \mathrm{a}$ & $2.16 \pm 0.09 \mathrm{a}$ & nd & nd \\
\hline \multirow[t]{4}{*}{ 2nd } & Chl $a$ & $1.75 \pm 0.12 \mathrm{a}$ & $1.64 \pm 0.03 \mathrm{a}$ & $2.27 \pm 0.14 \mathrm{a}$ & $2.25 \pm 0.08 \mathrm{a}$ \\
\hline & Chl $b$ & $0.69 \pm 0.05 \mathrm{a}$ & $0.59 \pm 0.02 \mathrm{a}$ & $0.78 \pm 0.03 \mathrm{a}$ & $0.76 \pm 0.03 \mathrm{a}$ \\
\hline & Chl $a / b$ & $2.57 \pm 0.18 \mathrm{a}$ & $2.79 \pm 0.04 \mathrm{a}$ & $2.91 \pm 0.10 \mathrm{a}$ & $2.95 \pm 0.04 \mathrm{a}$ \\
\hline & Chl total & $2.43 \pm 0.15 \mathrm{a}$ & $2.23 \pm 0.05 \mathrm{a}$ & $3.05 \pm 0.17 \mathrm{a}$ & $3.01 \pm 0.11 \mathrm{a}$ \\
\hline
\end{tabular}

${ }^{1}$ Values are means \pm SE of 6-7 plants. Means followed by the same letter within rows and leaves are not significantly different at $\mathrm{P}<0.05$.

${ }^{2}$ Not determined.

indication of plant adaptation to UV-B. Our results may indicate a high inherent concentration of UV-B absorbing compounds in sunflower plants and may partially explain the insensitivity of biomass and SLW to enhanced UV-B radiation. However, tissues without increased UV-B absorbing compounds may still have other protection mechanisms, such as epicuticular waxes and/or trichomes. Higher wax content on adaxial leaf surfaces was observed in response to enhanced UV-B radiation in cotton leaves (KAKANI et al., 2003a). Also, the protective effects of trichomes against UV-B radiation damage have been demonstrated by mechanically removing the trichomes of Verbascum speciosum (MANETAS, 2003). Thus, future studies should investigate the effects of UV-B on alternative protection mechanisms in sunflower plants.

In this study, enhanced UV-B radiation did not cause any damage to sunflower plants on the second sampling. This could be a consequence of shading by leaves as plants developed during the rapid growth period, resulting in lower levels and lower exposition time of leaves to UV-B radiation for the lower leaves compared to upper ones. These facts may mitigate against the detrimental effects of increased UV-B radiation on plants. Future studies should aim to investigate the effects of increased UV-B radiation in an early stage of development of sunflower plants and should include investigation of alternative defense mechanisms, such as epicuticular waxes, trichomes and antioxidants.

\section{ACKNOWLEDGMENTS}

I. Cechin thanks FAPESP-Fundação de Amparo à Pesquisa do Estado de São Paulo-Brazil and FUNDUNESP - Fundação de
Desenvolvimento da UNESP - Brazil, for financial support. The authors are greatful to CATI (Coordenadoria de Assistência Técnica Integral) for the supply of sunflower seeds.

\section{REFERENCES}

ALLEN, D.J. et al. Analysis of limitations to $\mathrm{CO}_{2}$ assimilation on exposure of leaves of two Brassica napus cultivars to UV-B. Plant Cell Environment, v.20, p.633-640, 1997.

ARNON, D.I. Copper enzymes in isolated chloroplasts. Polyphenol oxidases in Beta vulgaris. Plant Physiology, v.24, p.1-15, 1949 .

BARBOUR, M. G. et al. Light and temperature. In Terrestrial plant ecology. California: Benjamin/Cummings, 1987. Chap.14, p.326-355.

COOPER-DRIVER, G.A.; BHATTACHARYA, M. Role of phenolics in plant evolution. Phytochemistry, v.49, p.1165$1174,1998$.

DAY, Q. et al. Penetration of UV-B radiation in foliage: evidence that the epidermis behaves as a non-uniform filter. Plant, Cell and Environment, v.16, p.735-741, 1993.

DAI, T.A. et al. Effects of UVB radiation on stomatal density and opening in rice (Oryza sativa L.). Annals of Botany, v.76, p.65-70, 1995.

FENG, H. et al. The effect of enhanced ultraviolet-B radiation on growth, photosynthesis and stable carbon isotope composition $\left(\mathrm{d}^{13 \mathrm{C}}\right)$ of two soybean cultivars (Glycine max) under field conditions. Environmental and Experimental Botany, v.49, p.1-8, 2003

GAO, W. et al. Impact of enhanced ultraviolet-B irradiance on cotton growth, development, yield, and qualities under field conditions. Agricultural and Forest Meteorology, v.120, p.41-248, 2003

GITZ III, D.C. et al. Ultraviolet-B effects on stomatal density, water-use efficiency, and stable carbon isotope discrimination 
in four glasshouse-grown soybean (Glycine max) cultivars. Environmental and Experimental Botany, v.53, p.343$355,2005$.

GONZÁLEZ, R. et al. Non-photosynthetic mechanisms of growth reduction in pea (Pisum sativum L.) exposed to UV-B radiation. Plant, Cell and Environment. v.21, p.23-32, 1998.

HAKADA, et al. Sensitivity of crops to increased ultraviolet$B$ radiation in northern growing conditions. Journal of Agronomic Crop Science, v.188, p.8-18, 2002.

HEWITT, E.J. Sand and water culture methods used in the study of plant nutrition. England: Commonwealth Agricultural Bureaux of Technical Communications, Farnham Royal, 1966. 241p.

HOPKINS, L. et al. Ultraviolet-B radiation reduces the rates of cell division and elongation in the primary leaf wheat (Triticum aestivum L. cv Maris Huntsman). Plant, Cell and Environment, v.25, p.617-624, 2002.

JANSEN, M.A.K. et al. Higher plants and UV-B radiation: balancing damage, repair and acclimation. Trends in Plant Science, v.3, p.131-135, 1998.

JANSEN, M.A.K.; VAN DEN NOORT, R.E. Ultraviolet-B radiation induces complex alteration in stomatal behavior. Physiologia Plantarum, v.110, p.189-194, 2000.

JORDAN, B.R. The effects of ultraviolet-B radiation on plants: a molecular perspective. Advances in Botanical Research, v.22, p.97-162, 1996.

KAKANI, V.G. et al. Effects of ultraviolet-B radiation on cotton (Gossipum hirsutum L.) morphology and anatomy. Annals of Botany, v.91, p.817-826, 2003a.

KAKANI, V.G. et al. Field crop responses to ultraviolet-B radiation: a review. Agricultural and Forest Meteorology, v.120, p.191-218, 2003 b.

KERR, J.B.; McELROY, C.T. Evidence for large upward trends of ultraviolet-B radiation linked to ozone depletion. Science, v.262, p.1032-1034, 1993.

KOOSTRA, A. Protection from UV-B-induced damage by flavonoids. Plant Molecular Biology, v.26, p.771-774, 1994.

KRAUS, G.H.; WEISS, E. Chlorophyll fluorescence and photosynthesis: The basics. Annual Review of Plant Physiology, v.42, p.317-349, 1991.

LIU, L.-X. et al. Solar UV-B radiation on growth, photosynthesis and the xanthophyll cycle in tropical acacias and eucalyptus.
Environmental and Experimental Botany, v.54, p.121$130,2005$.

MANETAS, Y. The importance of being hairy: the adverse effects of hair removal on stem photosynthesis of Verbascum speciosum are due to solar UV-B radiation. New Phytologist, v.158, p.503-508, 2003.

MARK, U. et al. Effects of solar UVB radiation on growth, flowering and yield of central and southern european maize cultivars (Zea mays L.). Photochemistry and Photobiology, v.64, p.457-463, 1996.

MAZZA, C.A. et al. Functional significance and induction by solar radiation of ultraviolet-absorbing sunscreens in field-grown soybean crops. Plant Physiology, v.122, p.117-125, 2000.

MOLINA, M.J.; ROWLAND, F.S. Stratospheric sink for chlorofluoromethanes - Chlorine atomic-catalysed destrution of ozone. Nature, v.249, p.810-812, 1974.

NOGUÉS, S. et al. Ultraviolet-B radiation effects on water relations, leaf development, and photosynthesis in droughted pea plants. Plant Physiology, v.117, p.173-181, 1998.

NOGUÉS, S. et al. Characterization of stomatal closure caused by ultraviolet-B radiation. Plant Physiology, v.121, p.489496, 1999.

PINTO, M.E. et al. Effects of UV-B radiation on growth, photosynthesis, UV-B-absorbing compounds and NADP-malic enzyme in bean (Phaseolus vulgaris L.) grown under different nitrogen conditions. Journal of Photochemistry and Photobiology B, v.48, p.200-209, 1999.

ROBBERECHT, R.; CALDWELL, M.M. Leaf ultraviolet optical properties along a latitudinal gradient in the artic alpine life zone. Ecology, v.61, p.612-619, 1980.

SEARLES, P.S. et al. The response of five tropical dicotyledon species to solar ultraviolet-B radiation. American Journal of Botany, v.82, p.445-453, 1995.

SEARLES, P.S. et al. A meta-analysis of plant field studies simulating stratospheric ozone depletion. Oecologia, v.127, p.1-10, 2001.

VON CAEMMERER, S.; FARQUHAR, G.D. Some relationships between the biochemistry of photosynthesis and gas exchange of leaves. Planta, v.153, p.376-387, 1981.

ZHAO, D. et al. Growth and physiological responses to cotton (Gossypium hirsutum L.) to elevated carbon dioxide and ultraviolet-B radiation under controlled environment conditions. Plan, Cell and Environment, v.26, p.771-782, 2003. 